Working Paper in Economics No. 776

\title{
Past and present outage costs - A follow-up study of households' willingness to pay to avoid power outages
}

Fredrik Carlsson, Mitesh Kataria, Elina Lampi, and Peter Martinsson

Department of Economics, October 2019 


\title{
Past and present outage costs - A follow-up study of households' willingness to pay to avoid power outages
}

\author{
Fredrik Carlsson ${ }^{ \pm}$ \\ University of Gothenburg, Sweden \\ Mitesh Kataria ${ }^{\partial}$ \\ University of Gothenburg, Sweden \\ Elina Lampi* \\ University of Gothenburg, Sweden \\ Peter Martinsson ${ }^{\#}$ \\ University of Gothenburg, Sweden
}

\begin{abstract}
Households' demand for electricity continues to increase. This trend per se should indicate increased disutility from power outages. On the other hand, batteries and other back-up systems have been improved and the frequency and duration of outages have been reduced in many countries. By comparing the results from two stated preference studies on Swedish households' willingness to pay to avoid power outages in 2004 and 2017, we investigate whether the willingness to pay has changed. The willingness to pay is assessed for power outages of different durations, and whether it is planned or unplanned. We find three main differences: i) The proportion of households stating zero willingness to pay to avoid power outages decreased significantly from 2004 to 2017 and ii) the overall WTP was considerably higher in 2017 than in 2014, but iii) the WTP for duration of an outage has decreased. These results have implications for how regulators incentivize and regulate electricity suppliers since they suggest that a reliable supply of electricity is of greater importance now than what earlier studies have suggested.
\end{abstract}

JEL Classification: D12, Q40, Q41.

Keywords: Power outage, stated preferences, Sweden.

\footnotetext{
\pm Department of Economics, University of Gothenburg, Box 640, 40530 Gothenburg, Sweden; E-mail: fredrik.carlsson@economics.gu.se

D Department of Economics, University of Gothenburg, Box 640, 40530 Gothenburg, Sweden; E-mail: mitesh.kataria@economics.gu.se

* Department of Economics, University of Gothenburg, Box 640, 40530 Gothenburg, Sweden; E-mail: elina.lampi@economics.gu.se

\# Department of Economics, University of Gothenburg, Box 640, 40530 Gothenburg, Sweden; E-mail: peter.martinsson@economics.gu.se
} 


\section{Introduction}

Electricity is a key part of modern society and users in developed countries expect a reliable supply of electricity to meet their demand at all times. Historically, in Sweden, as well in other countries, most power outages in the electricity supply have been caused by failures in the electricity network, e.g., power line faults and damages on equipment such as generators and substations. Poor weather conditions, especially wind, have also caused many power outages. Over the past 20 years, there have been massive efforts to replace overhead power lines with underground dittos, which has resulted in both a reduced number of power outages and reduced outage durations (Swedish Energy Markets Inspectorate, R2018:16). For example, the frequency of power outages decreased from 1.4 to 1.2 outages per customer from 2003 to 2016 (Swedish Energy Markets Inspectorate, 2017). Moreover, the average duration decreased from 150 minutes to 75 minutes over the same period (Swedish Energy Markets Inspectorate, 2017). Alongside these improvements, a number of factors suggest that households have become more dependent on a reliable supply of electricity. Use of electricity has increased (Swedish Energy Agency, 2019), there are more electrical appliances in people's homes, and we are increasingly relying on things that need electricity in daily life such as smartphones, laptops, and electric vehicles (e.g., Wajcman, 2015; Sullivan and Gershuny, 2018). This suggests that households are more dependent on a reliable supply of electricity today than in the past, and it is likely that this trend will continue. The increased electricity use means both that a reliable supply is becoming increasingly important and that the increase in use can negatively affect the reliability of supply.

In this paper, we investigate whether and, if so, how Swedish households' willingness to pay (WTP) for a reliable electricity supply changed from 2004 to 2017. We do this by comparing responses to two stated preference surveys conducted in these years using the contingent valuation method (CVM). The surveys concerned people's willingness to pay to reduce power outages and were conducted among the general population in Sweden. The results from the 2004 study were originally presented in Carlsson and Martinsson (2007). In 2017, we conducted a similarly designed survey. Since both studies looked at the WTP to avoid power outages of different durations and at the effect of whether the outage was planned or unplanned, we provide some novel insights into whether and how people's WTP for a reliable supply of electricity has changed for various types of power outages in the past decade. An advantage of a follow-up study like ours is that it offers simple qualitative insights to the regulator about whether there is a need to improve the current reliability of the electricity 
supply in order to maintain the same degree of consumer satisfaction and, furthermore, about whether some specific groups are more vulnerable today than in the past. From a societal perspective, the results are of great importance for the determination of the optimal level of investment and maintenance in the network and the energy mix (Ambec and Crampes, 2012).

To measure households' costs of power outages, we make use of a stated preference method, more precisely the CVM, to elicit the WTP for a reduction in power outages. Stated preference studies have often been undertaken to support policymakers in their work to regulate the electricity industry. The results are often used as an input on how to incentivize maintenance of and investments in the network, Previous studies have shown that people have a sizeable WTP to reduce both the frequency and the duration of power outages (see, e.g., Amador et al., 2013; Baarsma and Hop, 2009; Carlsson, 2007; Cohen et al., 2016; Hensher et al., 2014: Moeltner and Layton, 2002). There are two main approaches to asking households to evaluate the effects of power outages. One involves directly asking them to state all of their direct costs for various types of outages (e.g., Wacker et al., 1985; Doane et al., 1988a). The other is to collect information on households' expenditures to reduce the negative effects of power outages. The main drawback with the two mentioned approaches, and the reason we use CVM, is that they do not include all welfare effects of an outage since non-market effects are not included. For households, not being able to use computers, charge smartphones, watch favorite TV shows, or cook food are probably the largest welfare effects of a power outage. The direct monetary effects are typically low, if any at all, at least for shorter power outages.

The rest of the paper is organized as follows. In Section 2, we give a brief description of the Swedish electricity market, in Section 3 we present the design of the two surveys conducted in 2003 and 2017, and in Section 4 we present the results from the two studies and compare the results. Section 5 concludes the article.

\section{The Swedish Electricity Market}

In Sweden, there is limited competition in the electricity grid market - a feature shared with many other countries. The regional and local electricity grid networks are owned by approximately 170 electricity grid companies, who are responsible for the distribution of electricity to customers from the state-owned national grid (Swedish Energy Markets Inspectorate, 2015). Electricity grid companies have exclusive rights in their geographical areas and thus have market power. The exclusive right is motivated by the fact that it is considered 
both economically and environmentally inappropriate to build parallel electricity networks across the country. Due to the lack of competition, the market for network companies is regulated by the Swedish Energy Markets Inspectorate, a public authority commissioned to strive for well-functioning energy markets. They regulate the electricity suppliers' economic returns using a performance-based regulation. The revenues are regulated based on the relative quality of each company, and one important aspect of the quality is the extent of power outages. In practice, laws and regulations set the minimum levels of quality. The network companies conduct risk and vulnerability analyses of their electricity networks and make action plans, which together with data on power outages are used by the Swedish Energy Markets Inspectorate to evaluate the delivery of electricity.

\section{Survey data from 2004 and 2017}

\subsection{4 survey}

The 2004 survey was part of a larger mail survey to households regarding their energy use. The sample was randomly drawn from a register containing all individuals between the ages of 18 and 75 years with a permanent address in Sweden. In the survey, each respondent was asked about their maximum WTP to avoid planned and unplanned power outages of various durations. In the contingent valuation scenario, the subjects were asked to state their maximum WTP, in an open-ended format, for avoiding a power outage of certain duration starting at 6 pm in January. The survey included questions for both planned and unplanned outages lasting $1,4,8$, or 24 hours. In addition, a valuation question for an unplanned outage of an uncertain duration (2-6 hours) was included. The survey was the result of a careful development process. Previous power outage surveys, e.g., Svenska Elverksföreningen (1994), served as valuable input together with collaboration with representatives from various power companies and researchers and engineers specializing in power outages. The survey was tested in smaller focus groups followed by a pilot survey before being finalized. The scenario and WTP questions in the 2004 study are shown in Figure 1.

We will now ask some questions regarding your household's willingness to avoid power outages. Imagine that there is a service with a backup electricity board that can be used in the case of a power outage. This electricity board would cover the household's need for electricity during the whole outage. You will only pay to the power company if an outage occurs. If you do not want to pay anything, your household will suffer from power outages. There are two types of outages, and we will ask you questions for both of these:

- Planned outage: An outage that you have been notified in advance about.

- Unplanned outage: An outage that comes as a surprise and that you have not been notified in advance about. 
Imagine that an outage occurs an evening in January and that it starts at $6 \mathrm{pm}$. For each question we ask you to answer how much your household is willing to pay in order to avoid this outage by connection to the service. We ask you to consider your answers as carefully as possible and to remember that it is possible to answer zero kronor as well.

\section{Planned outages}

How much would your household be willing to pay in order to avoid a power outage that starts at 6 pm an evening in January? You know in advance that the outage will occur. We ask you to answer all 4 questions below.

\begin{tabular}{l|l|r}
\hline & \multicolumn{1}{|c|}{ Duration of outage } & \multicolumn{2}{c}{ I'm willing to pay } \\
(round off to whole numbers)
\end{tabular}

\section{Unplanned outages}

How much would your household be willing to pay in order to avoid a power outage that starts at 6 pm an evening in January? You do not know in advance that the outage will occur. We ask you to answer all 5 questions below.

\begin{tabular}{l|l|r}
\hline & \multicolumn{1}{|c|}{ Duration of outage } & \multicolumn{1}{|c}{$\begin{array}{c}\text { I'm willing to pay } \\
\text { (round off to whole } \\
\text { numbers) }\end{array}$} \\
\hline Question 5 & 1 hour & SEK \\
\hline Question 6 & 4 hours & SEK \\
\hline Question 7 & 8 hours & SEK \\
\hline Question 8 & 24 hours & SEK \\
\hline Question 9 & $\begin{array}{l}\text { Between 2 and 6 hours. It is equally likely that the power } \\
\text { comes back on after 2 hours as after 6 hours, or any time in } \\
\text { between. }\end{array}$ & SEK \\
\hline
\end{tabular}

Figure 1. Contingent valuation scenario and questions in the 2004 study.

\subsection{7 survey}

The 2017 survey was developed based on the 2004 survey and again in collaboration with representatives from the industry and the regulator. A pilot study was conducted before the main survey. However, unlike the 2004 survey, a web-based survey was used instead of a mail survey. The main reason was that the response rate for mail surveys has decreased drastically in Sweden in the past 10 years.

Although the surveys from 2004 and 2017 are similar, there are a few differences that basically follow the development of the state-of-the-art practice of contingent valuation surveys. In the 2017 survey, we make use of a cheap-talk script (e.g., Cummings and Taylor, 1999) and emphasize consequentialism of the survey (Vossler et al., 2009). The cheap-talk script we included is shown in the top paragraph of the boxed text in Figure 2. The purpose of that paragraph is to highlight that there are potentially negative effects if one states a too high or too low WTP, and that we therefore encourage respondents to provide truthful responses. Consequentialism refers to the fact that it is important to make the respondents aware that their 
responses can actually have a real impact (Vossler et al., 2009). The text drawing the respondents' attention to this is found in the bottom paragraph of the box in Figure 2. Also note that in the 2004 survey, an open-ended contingent valuation question was used, while in the 2017 survey we used payment cards. For each duration of a power outage ( 3 minutes, 1 hour, 4 hours, and 12 hours), there were 27 different so-called bids to choose from, where the lowest was always zero. The WTP was elicited for both planned and unplanned power outages. We used a scale such that the bids and the intervals between the bids were increasing at an increasing rate (Rowe et al., 1996). The scenario and an example of a payment card used for planned power outages of 1 hour are shown below in Figure 2. 
We will now ask some questions about your household's willingness to pay to avoid a power outage. Imagine that there is a service offering a backup generator that can be used if there is a power outage. The generator can cover your household's need for electricity during a power outage. The service costs money but your household only pays to the network owner if a power outage occurs. If your household does not pay anything, you will not have access to the reserve generator during a power outage.

Imagine that a power outage will take place in January starting at $6 \mathrm{pm}$. For each question, we ask you how much your household would be maximum willing to pay in order to avoid this power outage by accessing the backup generator. We ask that you consider that the increased costs will reduce your ability to use the money for other purposes. There are no right or wrong answers.

Experiences from similar earlier studies show that some people tend to indicate a different willingness to pay in questionnaires than they in reality are willing to pay. Some indicate a lower amount. We believe this is partly because they want to express the opinion that they are entitled to uninterrupted delivery of electricity. Others indicate a higher amount. We believe that this is partly due to a desire to express that the electricity companies should take power outages very seriously. We ask that you answer according to what you would pay in reality for the backup service, because only then we will know what you actually think. If you specify a lower willingness to pay than your actual one, the service may not be made available to you, and if you exaggerate your willingness to pay, the service may be offered to you at the cost you stated.

The results from this study might influence the future of the electricity network and the level of the fees paid to the electricity network. The study is conducted on behalf of the Swedish Energy Agency.

How much would your household be willing to pay to avoid a planned power outage that starts at $6 \mathrm{pm}$ an evening in January? You know well in advance when the power outage will occur and that it will last 1 hour.

To answer, click the amount in SEK below that is closest to the maximum amount you would be willing to pay to avoid a planned power outage of 1 hour.

$\begin{array}{ccccccccc}0 & 5 & 6 & 7 & 9 & 11 & 13 & 16 & 19 \\ 23 & 28 & 34 & 40 & 50 & 60 & 75 & 90 & 110 \\ 130 & 160 & 190 & 230 & 280 & 340 & 415 & 500 & >500\end{array}$

Figure 2. Contingent valuation scenario and question about a planned 1-hour power outage in the 2017 survey 


\section{Results}

\subsection{Descriptive results}

To begin with, we present descriptive statistics for the two samples. In the 2004 study 1,678 individuals and in the 2017 study 1,547 individuals answered the survey. In both studies, some questions were not answered. In Table 1, we report descriptive statistics for the two samples.

Table 1. Descriptive statistics: Mean values and standard deviations in parentheses.

\begin{tabular}{|c|c|c|c|}
\hline Variable & Description & 2004 & 2017 \\
\hline & Geographic location & & \\
\hline Larger city & $=1$ if more than 100,000 inhabitants & 0.31 & 0.38 \\
\hline City & $=1$ if $1,000-100,000$ inhabitants & 0.53 & 0.49 \\
\hline Countryside & $\begin{array}{c}=1 \text { if fewer than } 1,000 \text { inhabitants } \\
\text { Housing }\end{array}$ & 0.16 & 0.11 \\
\hline House & $=1$ if detached home or townhouse & 0.63 & 0.57 \\
\hline Apartment & $=1 \mathrm{if} \mathrm{apartment}$ & 0.37 & 0.43 \\
\hline Size & Home size in square meters & $\begin{array}{l}114.7 \\
(57.6)\end{array}$ & $\begin{array}{l}113.7 \\
(61.9)\end{array}$ \\
\hline Cannot heat & $\begin{array}{l}\text { Heating } \\
=1 \text { if house cannot be heated during outages } \\
\text { Socio-economic characteristics }\end{array}$ & 0.40 & 0.38 \\
\hline Age & Age in years & $\begin{array}{c}48.66 \\
(15.12)\end{array}$ & $\begin{array}{c}45.39 \\
(16.07)\end{array}$ \\
\hline Male & $=1$ if male respondent & 0.50 & 0.50 \\
\hline Income & $\begin{array}{l}\text { Monthly household income after tax, } 2017 \\
\text { prices }\end{array}$ & $\begin{array}{c}28323 \\
(14092)\end{array}$ & $\begin{array}{r}36950 \\
(18481)\end{array}$ \\
\hline Household size & Total number of household members & $\begin{array}{l}2.48 \\
(1.27)\end{array}$ & $\begin{array}{c}2.52 \\
(3.07)\end{array}$ \\
\hline Kids in household & $=1$ if at least one child in the household & 0.24 & 0.23 \\
\hline $\begin{array}{l}\text { Number of } \\
\text { observations }\end{array}$ & & 1678 & 1547 \\
\hline
\end{tabular}

As shown in Table 1, there are some, but no considerable, differences between the two samples. The descriptive statistics show that the mean household income after tax is 30 percent higher in the 2017 sample when adjusting the 2004 incomes to 2017 prices. This increase corresponds to the average increase in disposable individual income over the same period, which after adjusting for inflation is 27.7 percent (SCB, 2019). ${ }^{1}$

In Table 2, we present descriptive statistics of the WTP responses to the various outage durations expressed in SEK per outage (2017 prices). ${ }^{2}$ More precisely, we report the mean values, medians, shares of positive WTPs, and the WTPs conditional on that a person has positive WTP.

\footnotetext{
${ }^{1}$ The average disposable income in Sweden was 200,100 SEK and 296,700 SEK in 2004 and 2017, respectively. If we adjust the 2004 figure for inflation, the average income was 232,407 SEK. Thus, the average income increased by 27.7 percent from 2004 to 2017, adjusted for inflation.

${ }^{2}$ Exchange rate in 2019 is $1 \mathrm{SEK}=0.09$ euro.
} 
Table 2. Stated WTP for different outages in SEK, 2017 prices, standard deviations in parentheses.

\begin{tabular}{|c|c|c|c|c|c|c|c|c|}
\hline & \multicolumn{4}{|c|}{2004} & \multicolumn{4}{|c|}{2017} \\
\hline & Mean & Median & $\begin{array}{l}\text { Share pos. } \\
\text { WTP }\end{array}$ & $\begin{array}{l}\text { Cond. } \\
\text { mean }\end{array}$ & Mean & Median & $\begin{array}{l}\text { Share pos. } \\
\text { WTP }\end{array}$ & $\begin{array}{l}\text { Cond. } \\
\text { mean }\end{array}$ \\
\hline \multicolumn{9}{|l|}{ Planned } \\
\hline 3 minutes & & & & & $\begin{array}{c}7.14 \\
(23.52)\end{array}$ & 0 & 0.24 & $\begin{array}{c}29.9 \\
(40.5)\end{array}$ \\
\hline 1 hour & $\begin{array}{c}8.87 \\
(68.9)\end{array}$ & 0 & 0.10 & $\begin{array}{c}84.8 \\
(198.0)\end{array}$ & $\begin{array}{c}25.51 \\
(56.37)\end{array}$ & 0 & 0.46 & $\begin{array}{c}55.9 \\
(72.6)\end{array}$ \\
\hline 4 hours & $\begin{array}{c}35.86 \\
(156.9)\end{array}$ & 0 & 0.26 & $\begin{array}{c}136.1 \\
(282.7)\end{array}$ & $\begin{array}{c}90.36 \\
(157.09)\end{array}$ & 33 & 0.70 & $\begin{array}{c}129.3 \\
(174.0)\end{array}$ \\
\hline 8 hours & $\begin{array}{l}103.38 \\
(309.2)\end{array}$ & 0 & 0.49 & $\begin{array}{c}209.1 \\
(414.0)\end{array}$ & & & & \\
\hline 12 hours & & & & & $\begin{array}{c}234.25 \\
(431.86)\end{array}$ & 110 & 0.82 & $\begin{array}{c}286.8 \\
(461.8)\end{array}$ \\
\hline 24 hours & $\begin{array}{l}243.25 \\
(704.6) \\
\end{array}$ & 58.07 & 0.61 & $\begin{array}{c}396.2 \\
(865.0) \\
\end{array}$ & & & & \\
\hline \multicolumn{9}{|l|}{ Unplanned } \\
\hline 3 minutes & & & & & $\begin{array}{c}7.53 \\
(23.26)\end{array}$ & 0 & 0.26 & $\begin{array}{c}28.6 \\
(38.1)\end{array}$ \\
\hline 1 hour & $\begin{array}{l}12.85 \\
(86.1)\end{array}$ & 0 & 0.14 & $\begin{array}{c}89.7 \\
(212.4)\end{array}$ & $\begin{array}{c}29.02 \\
(61.42)\end{array}$ & 0 & 0.49 & $\begin{array}{c}58.8 \\
(76.8)\end{array}$ \\
\hline 4 hours & $\begin{array}{c}46.61 \\
(148.8)\end{array}$ & 0 & 0.32 & $\begin{array}{c}146.7 \\
(234.7)\end{array}$ & $\begin{array}{c}106.96 \\
(186.38)\end{array}$ & 42 & 0.72 & $\begin{array}{c}148.1 \\
(204.9)\end{array}$ \\
\hline 8 hours & $\begin{array}{l}143.08 \\
(587.2)\end{array}$ & 17.42 & 0.54 & $\begin{array}{c}262.5 \\
(775.6)\end{array}$ & & & & \\
\hline 12 hours & & & & & $\begin{array}{c}264.74 \\
(502.67)\end{array}$ & 110 & 0.80 & $\begin{array}{c}329.0 \\
(541.2)\end{array}$ \\
\hline 24 hours & $\begin{array}{c}282.82 \\
(723.08)\end{array}$ & 104.53 & 0.64 & $\begin{array}{c}444.93 \\
(866.40)\end{array}$ & & & & \\
\hline
\end{tabular}

We can only make direct comparisons of the WTPs for 1 and 4-hour outages for both planned and unplanned outages. Consequently, we will focus on these outages at this stage. Mean WTP is considerably higher in the 2017 sample. For both planned and unplanned outages, the mean values were more than twice as high in 2017 than in 2004; using a t-test, all differences are statistically significant at the 1 percent level. As seen in Table 2, this is mainly due to the difference in share of respondents with a positive WTP. For each outage duration, a fraction of the respondents stated a zero WTP, and these shares were much higher in the 2004 study. For example, for a 1-hour planned outage, in 2004, 90 percent of the respondents were not willing to pay anything and thus only 10 percent had a positive WTP. In 2017, 46 percent had a positive WTP. If we instead look at conditional WTP, i.e., the WTP among those who stated a positive WTP, the differences between the two samples are much smaller. The conditional WTP was actually higher in 2004 than in 2017 for both planned and unplanned 1-hour outages, and the difference is statistically significant for unplanned outages ( $t$-test; $p$-value $=0.036$ ). Also for the 4-hour outages, the unconditional mean was more than twice as high in 2017 than in 2004, while the differences are again much smaller between the conditional WTPs. Thus, more 
individuals valuedpower outages in 2017 than in 2004, but among those who are willing to pay, the stated maximum payment did not increase. Note that both the number and duration of power outages clearly decreased from 2004 to 2017. According to the Swedish Energy Markets Inspectorate (2017), the number of power outages per electricity customer was about 1.4 per year in 2003. The corresponding number for the year 2016 was 1.2. Over the same period, the average duration of outages decreased from 150 minutes to 75 minutes.

Finally, the WTP is normalized to make WTP comparable among heterogeneous groups in terms of electricity use, which is standard in the literature and also what the industry prefers. The WTP for reducing power outages is then expressed as SEK per $\mathrm{kW}$. In order to proceed with the normalization, we use estimates of the mean max effect for households in Sweden. In the 2004 study, this value was estimated to $4.5 \mathrm{~kW}$. In the 2017 study, it was estimated to 5.3 $\mathrm{kW}$. In both cases, these figures are estimated using the average energy use and an assumption about the average usage time for households, which is assumed to be 1900 hour per year in Sweden. In order to make a direct comparison, we report the values for 2017 using both 4.5 $\mathrm{kW}$ and $5.3 \mathrm{~kW}$. Since we are only able to directly compare the 1- and 4-hour outages between the samples, we only report these values in Table 3 below.

Table 3. Normalized stated average WTP in SEK/kW.

\begin{tabular}{lccc}
\hline & $\mathbf{2 0 0 4}$ & $\mathbf{2 0 1 7}$ & $\mathbf{2 0 1 7}$ \\
\hline Max. effect & 4.5 & 4.5 & 5.3 \\
\hline Planned & & & \\
\hline 1 hour & 1.97 & 5.67 & 4.60 \\
& $(15.31)$ & $(12.52)$ & $(10.17)$ \\
4 hours & 7.97 & 20.08 & 16.31 \\
& $(34.86)$ & $(34.91)$ & $(28.35)$ \\
\hline Unplanned & & & \\
\hline 1 hour & 2.85 & 6.45 & 5.23 \\
& $(19.14)$ & $(13.65)$ & $(11.08)$ \\
4 hours & 10.36 & 23.77 & 19.31 \\
& $(33.07)$ & $(41.42)$ & $(33.64)$ \\
\hline
\end{tabular}

The table shows that the difference in average WTP in SEK for an outage also translates into differences in SEK per kW even if we use different normalizations. Thus, the large increases in WTP are not linearly related to the increase in energy use measured as the max effect.

\subsection{Econometric analysis}

As the next step to identify the determinants of WTP and to investigate what has changed over time, we estimate a WTP function using a pooled dataset from the 2004 and 2017 surveys. 
Since previous research has found that the WTP for a certain duration differs between planned and unplanned outages (see, e.g., Baarsma and Hop, 2009; Kim et al., 2015), we estimate a WTP function that allows for differences in valuation between these two types of outages. We express WTP as SEK per kW (4.5 kW for the 2004 sample and $5.4 \mathrm{~kW}$ for the 2017 sample). This means that the normalization differs between the two samples. However, the results are similar if we instead use the same normalization factor. Furthermore, both the WTP and the independent continuous variables are in log form. ${ }^{3}$ The models are estimated as Tobit models since the dependent variable is censored at zero. The standard errors are clustered at the household level. In the first model, we only include outage characteristics and a dummy variable equal to one if the response is from the 2004 survey. Next we include a set of socioeconomic characteristics. Finally, in the third model we include interaction terms between all the characteristics and the dummy variable for the 2004 survey. The main effect in the models is the effect of the determinant on WTP in the 2017 sample, while the interaction terms capture whether the change in WTP from 2004 to 2017 differs among different groups. The results are presented in Table 4.

\footnotetext{
${ }^{3}$ As discussed by Moeltner and Layton (2002), it is common in the literature to assume that both WTP and duration are in $\log$ form. The main reason for this is that it implies a concave and monotonically increasing relationship between WTP and duration. Since there are a number of observations with zero WTP, we actually recode the WTP values before the log transformation by adding the value 1 to all observations. The dependent variable then becomes $\ln (1)$. This also means that the censoring at 0 still is valid since $\ln (1)=0$.
} 
Table 4. Marginal effects Tobit model, dependent variable is $\operatorname{Ln}(\mathrm{WTP}+1)$. Robust standard errors in parentheses.

\begin{tabular}{|c|c|c|c|}
\hline & $(1)$ & $(2)$ & $(3)$ \\
\hline Old ( = 1 if 2004 study) & $\begin{array}{c}-1.069^{* * * *} \\
(0.042)\end{array}$ & $\begin{array}{c}-1.073^{* * *} \\
(0.045)\end{array}$ & $\begin{array}{c}-3.081^{* * *} \\
(0.928)\end{array}$ \\
\hline Log duration (hours): planned & $\begin{array}{c}0.514^{* * * *} \\
(0.011)\end{array}$ & $\begin{array}{c}0.513^{* * *} \\
(0.011)\end{array}$ & $\begin{array}{c}0.429^{* * *} \\
(0.011)\end{array}$ \\
\hline Log duration (hours): unplanned & $\begin{array}{c}0.507^{* * * *} \\
(0.010)\end{array}$ & $\begin{array}{c}0.507^{* * * *} \\
(0.010)\end{array}$ & $\begin{array}{c}0.416^{* * * *} \\
(0.010)\end{array}$ \\
\hline Planned & $\begin{array}{l}-0.168^{* * *} \\
(0.0432)\end{array}$ & $\begin{array}{c}-0.163^{* * * *} \\
(0.043)\end{array}$ & $\begin{array}{c}-0.138^{* * *} \\
(0.043)\end{array}$ \\
\hline House & & $\begin{array}{c}0.0974 \\
(0.065)\end{array}$ & $\begin{array}{l}0.133^{* *} \\
(0.067)\end{array}$ \\
\hline Ln (size) & & $\begin{array}{l}0.165^{\text {** }} \\
(0.071)\end{array}$ & $\begin{array}{l}0.0953 \\
(0.082)\end{array}$ \\
\hline Cannot heat & & $\begin{array}{c}0.211^{\text {*** }} \\
(0.047)\end{array}$ & $\begin{array}{c}0.217^{* * *} \\
(0.055)\end{array}$ \\
\hline City & & $\begin{array}{c}-0.0264 \\
(0.050)\end{array}$ & $\begin{array}{r}-0.0182 \\
(0.060)\end{array}$ \\
\hline Countryside & & $\begin{array}{c}-0.328^{\text {*** }} \\
(0.071)\end{array}$ & $\begin{array}{c}-0.260^{\text {**** }} \\
(0.086)\end{array}$ \\
\hline Male & & $\begin{array}{c}0.137^{* * *} \\
(0.044)\end{array}$ & $\begin{array}{l}0.0400 \\
(0.054)\end{array}$ \\
\hline Ln (income) & & $\begin{array}{c}0.161^{\text {*** }} \\
(0.047)\end{array}$ & $\begin{array}{c}0.169^{* * *} \\
(0.055)\end{array}$ \\
\hline Missing value income & & $\begin{array}{l}1.932^{* *} \\
(0.762)\end{array}$ & $\begin{array}{l}2.154^{* *} \\
(0.916)\end{array}$ \\
\hline Ln (household size) & & $\begin{array}{c}-0.0588 \\
(0.069)\end{array}$ & $\begin{array}{r}-0.0273 \\
(0.080)\end{array}$ \\
\hline Ln (age) & & $\begin{array}{c}-0.466^{* * * *} \\
(0.063)\end{array}$ & $\begin{array}{c}-0.425^{* * * *} \\
(0.071)\end{array}$ \\
\hline Have children & & $\begin{array}{l}0.0323 \\
(0.063)\end{array}$ & $\begin{array}{r}-0.0217 \\
(0.074)\end{array}$ \\
\hline Log duration (hours): planned $\times$ Old & & & $\begin{array}{c}0.378^{* * *} \\
(0.022)\end{array}$ \\
\hline Log duration (hours): unplanned $\times$ Old & & & $\begin{array}{c}0.334^{* * *} \\
(0.020)\end{array}$ \\
\hline Planned $\times$ Old & & & $\begin{array}{c}-0.384^{* * * *} \\
(0.088)\end{array}$ \\
\hline House $\times$ Old & & & $\begin{array}{l}-0.118 \\
(0.102)\end{array}$ \\
\hline Ln $($ size $) \times$ Old & & & $\begin{array}{c}0.181 \\
(0.134)\end{array}$ \\
\hline Cannot heat $\times$ Old & & & $\begin{array}{r}-0.0400 \\
(0.100)\end{array}$ \\
\hline City $\times$ Old & & & $\begin{array}{c}-0.0158 \\
(0.101)\end{array}$ \\
\hline Country side $\times$ Old & & & $\begin{array}{l}-0.121 \\
(0.155)\end{array}$ \\
\hline Male $\times$ Old & & & $\begin{array}{l}0.212^{* *} \\
(0.095)\end{array}$ \\
\hline Ln $($ income $) \times$ Old & & & $\begin{array}{c}-0.0203 \\
(0.096)\end{array}$ \\
\hline Missing value income $\times$ Old & & & $\begin{array}{l}-0.619 \\
(0.598)\end{array}$ \\
\hline Ln $($ household size $) \times$ Old & & & $\begin{array}{l}-0.107 \\
(0.148)\end{array}$ \\
\hline Ln (age) $\times$ Old & & & $\begin{array}{r}-0.0825 \\
(0.130)\end{array}$ \\
\hline Have children $\times$ Old & & & 0.139 \\
\hline
\end{tabular}


Model (1) confirms, as expected, the results from the descriptive statistics that there is an overall difference in WTP between the two survey rounds. This difference holds even if we control for socio-economic characteristics in Model 2. Model 3 is the most interesting and uses interaction terms to investigate changes between the two survey samples. The interactions between outage characteristics are all highly statistically significant. For outage duration, both interaction terms are positive. This suggests that the duration elasticities were higher in the 2004 study. For example, a 10 percent increase in the duration of a planned outage would increase WTP by about 4.3 percent in the 2017 sample and by approximately 8.1 percent in the 2004 sample. At the same time, the negative dummy variable for the 2004 survey was considerably larger in Model 3 than in the previous two models. Thus, there was a considerable overall increase in WTP from 2004 to 2017, but the results are not driven by a higher sensitivity to outage duration.

Among the other control variables, there is only one statistically significant interaction term, namely the interaction term between male and old version of the survey, which is positive and significant. While the main effect shows that there was no statistically significant difference in WTP between men and women in 2017, the interactions effects shows that in 2004, males had an approximately 23 percent higher WTP than women. ${ }^{4}$ Note that the lack of additional significant interaction terms means that positive and significant determinants such as living in a house, living in a home that cannot be heated during a power outage, and income affected WTP in a similar fashion in the two time periods. The income elasticity is not only similar between the two samples, but also similar to those obtained in other Swedish WTP studies on, e.g., improvements of air quality (Carlsson and Johansson-Stenman, 2000) and reduction of transport risks (Carlsson et al., 2004). We also found a number of negative and statistically significant determinants, such as age and living on the countryside, and again together with the insignificant interaction terms the results imply that the decreases in WTP for old people and people living in the countryside were similar in 2017 and 2004.

\footnotetext{
${ }^{4}$ For continuous linear independent variables the effect on the dependent variable is calculated using $\% \Delta y=$ $\exp (\hat{\beta})-1$. For a dummy variable that switches from 0 to 1 the effect is calculated using $\% \Delta y=$ $\left(\exp (\hat{\beta})-\frac{1}{2} \widehat{\operatorname{Var}}(\hat{\beta})\right)-1$ using the Kennedy (1981) approximation.
} 
We also estimate a probit model where we study the decision to state a positive WTP or not, where the dependent variable is equal to one if the WTP is greater than zero. These results are presented in Table 5.

Table 5. Marginal effects probit model, dependent variable is Prob[WTP $>0$ ]. Robust standard errors in parentheses.

\begin{tabular}{|c|c|c|c|}
\hline & $(1)$ & $(2)$ & $(3)$ \\
\hline Old ( = 1 if 2004 study) & $\begin{array}{c}-0.364^{* * * *} \\
(0.013)\end{array}$ & $\begin{array}{c}-0.370^{* * * *} \\
(0.014)\end{array}$ & $\begin{array}{c}-0.694^{* * * *} \\
(0.188)\end{array}$ \\
\hline Log duration (hours): planned & $\begin{array}{c}0.134^{* * *} \\
(0.003)\end{array}$ & $\begin{array}{c}0.137^{* * *} \\
(0.003)\end{array}$ & $\begin{array}{c}0.119^{* * *} \\
(0.003)\end{array}$ \\
\hline Log duration (hours): unplanned & $\begin{array}{c}0.131^{* * * *} \\
(0.003)\end{array}$ & $\begin{array}{c}0.133^{* * *} \\
(0.003)\end{array}$ & $\begin{array}{c}0.112^{* * * *} \\
(0.003)\end{array}$ \\
\hline Planned & $\begin{array}{c}-0.0551^{* * *} \\
(0.013)\end{array}$ & $\begin{array}{c}-0.055^{* * *} \\
(0.013)\end{array}$ & $\begin{array}{c}-0.0518^{* * * *} \\
(0.014)\end{array}$ \\
\hline House & & $\begin{array}{c}0.019 \\
(0.022)\end{array}$ & $\begin{array}{l}0.0310 \\
(0.024)\end{array}$ \\
\hline Ln (size) & & $\begin{array}{l}0.037 * \\
(0.022)\end{array}$ & $\begin{array}{l}0.0241 \\
(0.028)\end{array}$ \\
\hline Cannot heat & & $\begin{array}{c}0.054^{* * *} \\
(0.016)\end{array}$ & $\begin{array}{c}0.0648^{* * * *} \\
(0.021)\end{array}$ \\
\hline City & & $\begin{array}{l}-0.005 \\
(0.017)\end{array}$ & $\begin{array}{l}-0.0112 \\
(0.023)\end{array}$ \\
\hline Countryside & & $\begin{array}{c}-0.105^{* * *} \\
(0.026)\end{array}$ & $\begin{array}{c}-0.0889^{* *} \\
(0.035)\end{array}$ \\
\hline Male & & $\begin{array}{l}0.046^{* * *} \\
(0.015)\end{array}$ & $\begin{array}{l}0.0213 \\
(0.022)\end{array}$ \\
\hline Ln (income) & & $\begin{array}{c}0.030^{*} \\
(0.016)\end{array}$ & $\begin{array}{c}0.0359^{*} \\
(0.023)\end{array}$ \\
\hline Missing value income & & $\begin{array}{l}0.257 * \\
(0.149)\end{array}$ & $\begin{array}{c}0.324^{*} \\
(0.185)\end{array}$ \\
\hline Ln (household size) & & $\begin{array}{l}-0.029 \\
(0.024)\end{array}$ & $\begin{array}{c}-0.0232 \\
(0.032)\end{array}$ \\
\hline Ln (age) & & $\begin{array}{c}-0.151^{\text {**** }} \\
(0.022)\end{array}$ & $\begin{array}{c}-0.155^{\text {*** }} \\
(0.028)\end{array}$ \\
\hline Have children & & $\begin{array}{c}0.021 \\
(0.021)\end{array}$ & $\begin{array}{c}0.00143 \\
(0.029)\end{array}$ \\
\hline Log duration (hours): planned $\times$ Old & & & $\begin{array}{c}0.0863^{* * * *} \\
(0.007)\end{array}$ \\
\hline Log duration (hours): unplanned $\times$ Old & & & $\begin{array}{c}0.0767^{* * * *} \\
(0.007)\end{array}$ \\
\hline Planned $\times$ Old & & & $\begin{array}{c}-0.0968^{* * *} \\
(0.029)\end{array}$ \\
\hline House $\times$ Old & & & $\begin{array}{l}-0.0417 \\
(0.032)\end{array}$ \\
\hline $\operatorname{Ln}($ size $) \times$ Old & & & $\begin{array}{l}0.0302 \\
(0.042)\end{array}$ \\
\hline Cannot heat $\times$ Old & & & $\begin{array}{r}-0.0307 \\
(0.038)\end{array}$ \\
\hline City $\times$ Old & & & $\begin{array}{l}0.0131 \\
(0.034)\end{array}$ \\
\hline Country side $\times$ Old & & & $\begin{array}{r}-0.0257 \\
(0.053)\end{array}$ \\
\hline Male $\times$ Old & & & $\begin{array}{l}0.0520^{*} \\
(0.030)\end{array}$ \\
\hline Ln $($ income $) \times$ Old & & & -0.0114 \\
\hline
\end{tabular}




\begin{tabular}{|c|c|c|}
\hline \multirow{2}{*}{\multicolumn{2}{|c|}{ Missing value income $\times$ Old }} & $(0.032)$ \\
\hline & & $\begin{array}{l}-0.261 \\
(0.245)\end{array}$ \\
\hline \multicolumn{2}{|l|}{ Ln $($ household size $) \times$ Old } & $\begin{array}{l}-0.0205 \\
(0.049)\end{array}$ \\
\hline \multicolumn{2}{|l|}{ Ln (age) $\times$ Old } & $\begin{array}{l}0.009 \\
(0.043)\end{array}$ \\
\hline \multicolumn{2}{|l|}{ Have children $\times$ Old } & $\begin{array}{l}0.0468 \\
(0.043)\end{array}$ \\
\hline Observations & 23,986 & 23,986 \\
\hline
\end{tabular}

The results are very similar to the ones for the tobit model. There is a considerable overall difference in the likelihood of having a positive WTP between the two samples. In Model 2 the likelihood of having a positive WTP is approximately 31 percentage points smaller in the 2004 sample. When we introduce the interaction terms, this overall difference increases, the likelihood of having a positive WTP is approximately 51 percentage points smaller in the 2004 sample. At the same time, the interaction terms reveal that the subjects in the 2004 sample were disproportionality less likely to report a zero WTP for longer outage durations, both for planned and unplanned outages. Among the socio-economic characteristics, we again find that the only difference is that the gender difference in 2004 is not present in the 2017 sample. In 2004, males were approximately five percentage points more likely than females to have a positive WTP to avoid power outages.

\section{Conclusions}

In recent decades, households have acquired more appliances and electronic devices, especially computers and smartphones, but also other energy-demanding products such as electric vehicles, resulting in an increased demand for electricity. This demand for electricity requires a reliable supply of electricity.

We used a survey method to measure willingness to pay to reduce power outages both in 2004 and 2017 among the general population in Sweden. This gave us a unique opportunity to look at whether preferences for a reliable supply of electricity have changed over time within the same country. We find that for both planned and unplanned outages, mean values are more than twice as high in 2017 than in 2004 when adjusted for inflation. The major explanation for this is that a significantly lower share of respondents stated zero WTP in 2017 than in 2004. For an outage duration of one hour, the decrease in zero WTPs in 2017 was 36 percentage points, and for a 4-hour outage, the reduction amounted to 44 percentage points. Thus, it seems that people on average have become more sensitive to power outages per se in 2017 , including 
shorter ones. The main message from our study is that a reliable supply of electricity is of greater importance now than what earlier studies have suggested.

However, the differences in conditional WTP between the two samples are much smaller or in some cases also reversed. For example, the conditional WTP was higher in 2004 than in 2017 for both planned and unplanned 1-hour outages. Households in the 2004 survey were also more sensitive to the the duration of an outage compared with those who answered the 2017 survey.

While the surveys in 2004 and 2017 are similar, as already mentioned, they are not identical. The state of the art design of these surveys has changed since 2004, and today it is more common to take additional measures to mitigate hypothetical biases than in the past. This usually results in lower WTP measures. On the contrary, however, our results show that people on average have higher WTP and have become more sensitive to power outages, and therefore the results cannot be explained by the differences between the two survey versions.

Among the other control variables, we find several similarities between the 2004 and 2017 samples. For example, older people and respondents who live in the countryside have a significantly lower WTP in both cases. Moreover, in both studies, WTP is higher if the home cannot be heated during an outage. The income elasticity is also similar between the two samples. On the other hand, we find that respondents who live in a house had on average a higher WTP in the 2017 survey than in the 2004 survey. And, the size of the house is statistically significant in the 2004 survey, but not in the 2017 survey. Interestingly, the difference between males and females in conditional WTP had disappeared in 2017. In 2004, males had a 23 percent higher WTP (among those with a positive WTP) than females, but in 2017 there were no significant differences in stated WTPs between males and females. This might indicate that males and females had become more equally dependent on electricity compared with in 2004.

The novelty of our study is that our analyses draw from two similar surveys conducted 13 years apart, allowing us to investigate whether people's WTP for avoidance of power outages changed during a period when the dependency on electricity increased and better batteries and back-up systems became available. For policymakers, the detailed analyses for example of the determinants of these changes are important for future investments and regulation of the energy sector. Given the fast changes in the usage of various electronic appliances and the need for a reliable power supply, we hope that future studies will continue our line of research and test the robustness of our findings. 


\section{Acknowledgments}

We have received funding from the Swedish Energy Agency. We are grateful for valuable comments and feedback from Elin Grahn and Carl-Johan Wallnerström. In addition, the following persons have provided comments on the survey design and instrument: Lina Bertling (KTH Royal Institute of Technology), Kenny Granath (Mälarenergi), Anton Nordström (Vattenfall), Gerd Kjölle (SINTEF), Jenny Paulinder (Göteborg Energi), Yalin Huang (the Swedish Energy Markets Inspectorate), Torbjörn Severinsson (Vattenfall), Anders Petterson (Energiföretagen), Olle Hansson (Ellevio), and Erik Lejerskog (Ellevio).

\section{References}

Amador F. J., R. M. González, and F. J. Ramos-Real (2013). Supplier choice and WTP for electricity attributes in an emerging market: The role of perceived past experience, environmental concern and energy saving behavior, Energy Economics, 40, 953-966.

Ambec, S. and C. Crampes (2012). Electricity provision with intermittent sources of energy, Resource and Energy Economics 34, 319-336.

Baarsma B. E., and J. P. Hop (2009). Pricing power outages in the Netherlands, Energy, 34, 1378-1386.

Carlsson F., and O. Johansson-Stenman (2000). Willingness to pay for improved air quality in Sweden, Applied Economics, 32, 661-670.

Carlsson, F. O. Johansson-Stenman and P. Martinsson (2004). Willingness to pay for reductions in fatal risks in public transports, Journal of Risk and Uncertainty, 28, 147-163.

Carlsson, F., and P. Martinsson (2007). Willingness to pay among Swedish households to avoid power outages: a random parameter Tobit model approach, The Energy Journal, 28, 75-90.

Cohen, J., K. Moeltner, J. Reichl, and M. Schmidthaler (2016). Linking the value of energy reliability to the acceptance of energy infrastructure: Evidence from the EU. Resource and Energy Economics 45, 12-143.

Cummings, R.G. and L.O. Taylor (1999). Unbiased Value Estimates for Environmental Goods: A Cheap Talk Design for the Contingent Valuation Method, American Economic Review, 89, 649-65.

Doane, M. J., \& Hartman, R. S. (1988). Households' Perceived Value of Electrical Service Reliability: An Analysis of Contingent Valuation Data. The Energy Journal.

Energimarknadsinspektionen (2015). Kvalitetsreglering av intäktsram för elnätsföretag Reviderad metod inför tillsynsperiod 2016-2019, Rapport Ei R2015:06.

Energimarknadsinspektionen (2017). Leveranssäkerhet i Sveriges elnät 2016 - Statistik och analys av elavbrott, Rapport Ei R2017:11.

Hensher D. A., N. Shore and K. Train (2014). Willingness to pay for residential electricity supply quality and reliability, Applied Energy, 115, 280-292.

Johansson, B., (2013). Security aspects of future renewable energy systems - A short overview, Energy 61, 598-605.

Kennedy, P. E. (1981). Estimation with correctly interpreted dummy variables in semilogarithmic equations [the interpretation of dummy variables in semilogarithmic equations], American Economic Review, 71(4), 801-801.

Kim K., H. Nam, and Y. Cho (2015). Estimation of the inconvenience cost of rolling blackout in the residential sector: The case of South Korea, Energy Policy, 76, 76-86. 
Moeltner, K. and D. Layton (2002). A Censored Random Coefficients Model for Pooled Survey Data with Application to the Estimation of Power Outage Costs, Review of Economics and Statistics, 84, 552-561.

Rowe, R. W. Schulze, and W. Breffle (1996). A Test for Payment Card Biases. Journal of Environmental Economics and Management 31, 178-185.

Sullivan, O. and J. Gershuny (2018). Speed-up society? Evidence from the UK 2000 and 2015 time use diaries, Sociology, 52, 20-38.

SCB (2019). https://www.scb.se/hitta-statistik/statistik-efter-amne/hushallensekonomi/inkomster-och-inkomstfordelning/inkomster-och-skatter/ (Accessed 2019-0909).

Svenska Elverksföreningen (1994). Avbrottskostnader för Elkunder. Svenska Elverksföreningen, Stockholm.

Svenska Kraftnät (2017). Systemutvecklingsplan 2018-2027 - Mot ett flexibelt kraftsystem i en föränderlig omvärld.

Swedish Energy Agency (2019). Energy in Sweden 2019. Swedish Energy Agency, Eskilstuna Sweden.

Vossler, C.A., and M.F. Evans. (2009). Bridging the Gap between the Field and the Lab: Environmental Goods, Policy Maker Input, and Consequentiality. Journal of Environmental Economics and Management, 58, 338-345.

Wajcman, J., (2015). Pressed for Time: The Acceleration of Life in Digital Capitalism. Chicago, IL: University of Chicago Press.

Wacker, G., R. K. Subramaniam, and R. Billington (1985). Using Cost of Electric Service Interruption Surveys in the Determination of a Composite Customer Damage Function. International Journal of Energy Systems, 5, 100-104. 